\title{
The students problems in junior high school
}

\author{
Nurhasanah Nurhasanah ${ }^{*}{ }^{1}$, Muh.Farozin $^{2}$ \\ ${ }^{1}$ Universitas Negeri Yogyakarta, ${ }^{2}$ Universitas Negeri Yogyakarta \\ *) Corresponding author, $\equiv$ e-mail: nurhasanahrahman04gmail.com
}

\begin{abstract}
Problem is a condition which doesn't meet the expectation rightly and it must be solved directly. In early phase of adolescent, the Junior High School students are always find the highest changes in their selves which can cause a problem. Because of that, the guidance and counseling services should be provided based on the students' need that related to their problem experienced. On the flip side, the school counselor have difficulties to identify those problems that can influence in giving services. Then, this research focus on the students' problem experienced of junior high school which has 193 students as a respondent. Therefore, all of them are students of junior high school in Yogyakarta. Furthermore, the method on this research is service method by using a guidance and counseling problem-based instrument namely Alat Ungkap Masalah (AUM) Umum. The result in this research showed that they are three categories of problems experienced by students in junior high school Yogyakarta as the highest one. They are (1) Social Relationship which got $45 \%$, (2) Personality got around $44 \%$ and (3) Physical Health is about $40 \%$.
\end{abstract}

Keywords:Student Problem, Junior High School, Guidance and Counseling.

How to Cite: Nurhasanah, N., \& Farozin, M. (2019). The problems of junior high school students. COUNS-EDU: The International Journal of Counseling and Education, 4(3), 129-133. DOI:http:// doi.org/10.23916/0020180316340

\section{Introduction}

Junior high-school student in their developmental stages are classified as early adolescents. Santrock (2014) mentions adolescence as a transitional period of development that begins around the age of 10 to 12 years, and ends at the age of 18 to 22 years. This stage of adolescence is a transition from childhood to adulthood where there will be many changes that occur.Adolescence is a developmental transition involving physical, cognitive, psychosocial changes, from childhood to adulthood, (Papalia et al, 2008). These changes can be seen from biological, emotional to cognitive. Santrock (2011) argues that among the cognitive changes that occur during the transition from childhood to adolescence is an increase in abstract, idealistic, and logical thinking. This will be a problem if students cannot handle changes. Basically, the problem experienced by the learner can be specifically identified, where the competent educator in the case is the school counselor. As in school, guidance and counseling also require student need's analysis (Ratnawulan, 2017).Before school counselor provide guidance and counseling services first need to do understanding of students an understanding of the potential, abilities, characteristics, needs and problems it faces.Gysbers \& Henderson (2012) the middle school or junior high school level, students can gain assistance in such areas as career planning, high school educational opportunities, community involvement, and recreational opportunities.

Student issues need to be identified by guidance and counseling teachers who will impact on guidance and counseling services. The process of discovering the problems that students experience can be done using a guidance and problem-based counseling instrument. Some researchers have pointed out that 
school students are people who are experiencing change that can pose problems to him. Desmita (2015) characteristic of junior high school students have unstable reactions and emotional expressions. Intelligence of junior high school students is low, Lestari (2012). Given that emotional intelligence is one of the capitals for learners in life that must be grown so that students can become human beings capable of controlling various aspects that exist in him. Students at this stage have new demands to be met in both the school, family and community environments. It takes students to have their own mindset in solving problems encountered. Confusion, changes and demands that exist make students experience stress, become unstable, difficult to understand. The immorality of students' thinking according to David Elkin (in Papalia, et al., 2008) is manifested in six characteristics: (1) Idealism and criticality, (2) Argumentativity, (3) hesitation, (4) hypocrisy, (5) self-awareness, (6) specificity and resilience.

Hendri et al (2014) showed that the average junior-highschoolstudent who commits the violation is seen from the school entrance aspect of $61.39 \%$ in the medium category, and the learning time violation is $62.54 \%$ in the high category. In addition to the problems in violations that exist within the school, the learner also has problems on his mind. Park et al (2017) writes that the mindset of learners as adolescents can also affect their academic achievement. On the other hand the mistake of the learner in thinking of course can cause other problems in him. Wendari, et al (2016) revealed that junior high school students overall are in the category of problem (57.65\%). Students who have problems will affect the mindset until the behavior disclosed by Fitri (2017) in his research shows the social adjustment of junior high school students affects the students' academic achievement of $17.5 \%$. Problems related to the psychological condition of the students include problems with feelings of alienation and isolation from the community, as well as issues related to anxiety and concerns about the educational process and learning outcomes Pozdnyakova (2017).

However, in fact Jannah (2010) the results of his research revealed the factors that cause the lack of guidance and maximum school counselor to carry out analysis of junior-high school students is limited time, energy, and limited costs. As an educator, school counselor have the responsibility and duty to assist students in achieving optimum development. As explained in the Regulation of the Minister of Education and Culture of the Republic of Indonesia Number 111 of 2014 that the general purpose of guidance and counseling services is to assist students in order to achieve maturity and independence in life and carry out developmental tasks including personal, social, learning and career intact and optimal. Guidance and counseling services are services that consist of various concepts and methods and are tailored to the needs of the students. To be able to carry out their duties and responsibility'sschool counselorhas an important role in identifying students' problems at school as the main foundation of the counseling and guidance service itself.

This study aims to uncover the problems that occur in juniorhigh-school students by using the Alat Ungkap Masalah (AUM) Umum instrument. AUM Umum as a tool to express the problem is a fairly simple and easy to use instrument to reveal various problems experienced by learners Prayitno (2017). Issues that can be disclosed to include areas of personal, social, learning and career issues. In addition, the benefits of this research are as early information that can be used by guidance and counseling teachers in the design of guidance and counseling services in junior high school. AUM is one of the guidance and counseling instruments that are widely used guidance and counseling teachers in Indonesia who have high validity and reliability. AUM is used as a tool to express problems experienced by students. AUM instrument's format two for junior high- school consists of ten problem areas and 155 problem items. This instrument is then given to junior high school students in Yogyakarta.

\section{Method}

According to Sugiyono (2014) population is a region of generalization, objects / subjects that have certain qualities and characteristics set by the researchers to be studied and then drawn conclusions. Explain Arikunto (2010) population is the whole of the study subjects. This research use survey method, that is research conducted by using questionnaire as research tool which done on big and small population (Sugiyono, 2013). Survey research methods include survey development, sample selection and survey administration, and data analysis and reporting (Fink, 2013). The instrument used is Alat Ungkap Masalah (AUM) Format two for Junior high school. AUM Umum has its validity and reliability. This instrument is given to junior high school students in Yogyakarta, amounting to 193 people, to assist students in finding the problems they experienced. The results of the answers selected by the students then analyzed teacher guidance and counseling. The results of the analysis will show the highest problems 
experienced by junior high school students, and will serve as the basis for the provision of guidance and counseling services.

\section{Results and Discussions}

Data from the Alat Ungkap Masalah (AUM) Umum sees the highest problem experienced by Junior-high school students in Yogyakarta and the lowest problem. These problems can then determine guidance and counseling services for learners.Based on the results instruments of Alat Ungkap Masalah (AUM) Umum format two can be found out the data results of the group of junior High-school students in table 1 below.

Table 1. Results of data group of junior high school students

\begin{tabular}{lccc}
\hline \multicolumn{4}{c}{ Overall Problems } \\
Field Issues & $\begin{array}{c}\text { Amoun } \\
\text { t }\end{array}$ & $\begin{array}{c}\text { Percentage } \\
(\%)\end{array}$ & $\begin{array}{c}\text { The Average } \\
\text { Student }\end{array}$ \\
\hline Physical Healthy & 400 & 40 & 2 \\
Personality & 1107 & 44 & 6 \\
Social Relationship & 1127 & 45 & 6 \\
Career and Work & 134 & 27 & 1 \\
Economy and Finance & 156 & 16 & 1 \\
Education and Lessons & 252 & 17 & 1 \\
Religion, Values, an Morals & 227 & 23 & 1 \\
Relationship of Young People & 180 & 36 & 2 \\
Circumstances and Relationships Within the & 330 & 13 & 1 \\
Family & 169 & 34 & \\
Leisure Time & & & 2 \\
\end{tabular}

The result of group data in table 1 above can be seen that on the whole problem, the highest problem is in the field of Social Relations problem with the number of 1127 problems or $45 \%$ where each student has 6 problems in that field. While the lowest problem is in the field of Career and Employment problems with the number of 134 problems or $27 \%$ where each student has one problem in the fieldBased on the results of the above group data, it can be seen in detail the three highest problems experienced by junior High-school students in Yogyakarta in table 2 below.

Table 2. The highest problem of junior high school students

\begin{tabular}{lrcc}
\hline \multicolumn{3}{c}{ Overall Problems } \\
\hline Field Issues & Amount & Percentage $(\%)$ & The Average Student \\
\hline Social Relationship & 1127 & 45 & 6 \\
Personality & 1107 & 44 & 6 \\
Physical Healthy & 400 & 40 & 2 \\
\hline
\end{tabular}

The three highest problems experienced by junior high school participants can be seen in table 2 above. The first highest problem is in the field of Social Relations problems with the number of 1127 problems or $45 \%$ in which each student has 6 problems. The second highest problem is in the Personal Problem area with the number of 1107 problems or $44 \%$ where each student has 6 problems in the field of personal issues. Furthermore, the third highest problem is in the area of physical and health problems with a total of 400 problems or $40 \%$ in which each student has 2 problem problems. 
The junior high school student starts facing a problem that may be felt when he is in this teenage phase. These problems can be handled well if the student has the ability to control himself. School counselors in this case facilitate students in solving problems. It is not uncommon to see that junior high school students have issues that affect behavior by the way they socialize with others. It is not easy to handle the problems experienced in this phase considering the number of students from the tribe to the existing social-economic level, one of them in the first junior high school students in Yogyakarta. As in table two above it is seen that the highest problem experienced by junior high school students in Yogyakarta is a social problem. Myrick (2011) describes the challenges of counseling and mentoring in junior high schools centered on the physical, intellectual, emotional, and social development that comes with early adolescence. This suggests that challenges to help students cope with their social development, foster friendships with peers, can communicate well and have sincere friendship. Yusuf and Sugandhi (2014) write that social development is the result of social relationships between norms, morals, and traditions, which combine together, communicate, and work together.

Previous research conducted by Izal (2015) reveals junior high-school students in Padang who have the highest problems in personal matters. On the contrary similar research results have also been conducted Gonal (2016) has shown that junior high-school students in Kupang have problems with social problems. The goal of social achievement (different orientation towards social competence) is an important aspect of youth social motivation, Ryan (2008). Based on this issue, guidance and counseling teachers will provide guidance and counseling services that meet the needs of learners and facilitate participants to solve the problems they face. Social problems facing students are important to provide a multicultural and interdisciplinary approach, Faris (2015). Shaterloo, et al (2011) included that school counselorsupport learners in their academic processes to foster, improve interpersonal competence and improve academic achievement.

Based on the results of the research in Table 2 above shows the highest problem experienced by junior high school students in Yogyakarta on social relations. Students who have high social problems such as difficulty getting along, choosing close friends, to low social interaction ability will affect other problems that arise. It is necessary to obtain counseling and guidance services from school counselor so that student problems can be solved without causing any new problems.

\section{Conclusions}

The junior high school participant will experience various problems that can change the mindset until the behavior if the problem cannot be handled properly. This is where the provision of guidance and counseling services should be provided in accordance with needs. The problems experienced by junior high-school students are identified by the problem-based instruments commonly used by guidance and counseling teachers in Indonesia. The instrument is an Alat Ungkap Masalah (AUM) Umum format two for a secondary school.

This study identifies three of the highest problems faced by junior high school students in Yogyakarta covering the areas of Social Relations problems of $45 \%$, personal problems of $44 \%$, and Physical and Health by $40 \%$. This indicates that junior high school students experience social relations attitude that is closed with the problems they experienced. These problems will not be separated from the supervision and handling of school counselor in providing guidance and counseling services in accordance with the problems and needs experienced by student. Identifying the problems of these student will greatly help teachers guidance and counseling to facilitate student until the problems they encounter can be solved.

\section{References}

Arikunto, Suharsimi. (2010). Anggaran Perusahaan. Jakarta: Rineka Cipta.

Desmita. (2015). Psikologi Perkembangan Peserta Didik. Bandung: PT. RemajaRosdakarya.

Farris, P. J. (2015). Elementary and middle school social studies: An interdisciplinary, multicultural approach. Waveland Press.

Fitri, N. L. (2017). Pengaruh penyesuaian diri dan penyesuaian sosial terhadap prestasi akademik siswa. Jurnal Riset Mahasiswa Bimbingan Dan Konseling, 3(8), 454-465.

Fink, A. (2013). How to conduct surveys: A step-by-step guide ( $5^{\text {th }}$ ed.). thousand Oaks, Ca: Sage. 
Gonal, Hildegardis. (2016). Profil Interaksi Sosial Dan Implikasinya Bagi Layanan BimbinganSosial. ThesisUniversitas Katolik Widya Mandira.

Gysbers, N.C., Henderson, P. (2012). Developing \& Managing Your School Guidance \& Counseling Program. Alexandria: ACA Wiley.

Hendri, Y., Daharnis, D., \& Nurfahanah, N. (2016). Pelanggaran Tata Tertib yang dilakukan oleh Siswa Di sekolah dan Implikasinya terhadap Pelayanan Bimbingan dan Konseling. Konselor, 3(2), 47-52.

Izal, M. (2015). Identifikasi permasalahan siswa dan upaya gururnbimbingan konseling dalam menanganinyarn (suatu penelitian di Smp Negeri 17 Banda Aceh). ETD Unsyiah.

Jannah, W. (2010). Pelaksanaan analisis masalah siswa berdasarkan hasil alat ungkap masalah umum (aum u-3) di sekolah menengah pertama negeri 25 pekanbaru (Doctoral dissertation, Universitas Islam Negeri Sultan Syarif Kasim Riau).

Lestari, I. (2012). Pengembangan Model Bimbingan Kelompok Dengan Teknik Simulasi untuk Meningkatkan Kecerdasan Emosi Siswa. Jurnal Bimbingan Konseling, 1(2).

Myrick, Robert D. 2011. Developmental Guidance and Counseling : A Practical Approach Fifth edition. Minneapolis : Educational Media Corporation.

Papalia, Diane E, et al. (2008). Human Development (Psikologi Perkembangan), Terjemahan A.K Anwar. Jakarta:Kencana.

Park, et al. (2017). Analysis of Gender Differences for Enhancing Learners'Computational Thinking Ability-From the Personal Charateristics and Coding Preference Point of View. Journal of Educational Management.

Peraturan Menteri Pendidikan dan Kebudayaan Republik Indonesia Nomor 111 Tahun 2014. Tentang Bimbingan dan Konseling Pada Pendidikan Dasar dan Menengah.

Pozdnyakova, O., \& Pozdnyakov, A. (2017). Adult Students' Problems in the Distance Learning. Procedia Engineering, 178, 243-248.

Prayitno. (2017). Panduan Alat Ungkap masalah Umum (AUM Umum). Universitas Negeri Padang

Ratnawulan, T., \& Rahman, S. A. (2017). Management profile of guidance and counseling in junior high school. People: International Journal of Social Sciences, 3(3).

Ryan, A. M., \& Shim, S. S. (2008). An exploration of young adolescents' social achievement goals and social adjustment in middle school. Journal of Educational Psychology, 100(3), 672.

Santrock, J.W. (2011). Life-Span Development $3^{\text {rd }}$ edition. USA: McGraw-Hill.

Santrock,J.W. (2014). Adolescence fifteenth edition. USA: McGraw-HillEducation.

Shaterloo, et al. (2011).Students Counselling and Academic Achievement. Procedia-Social and Behavioral Science. 3(2011), 625-628.

Sugiyono. (2013). Metode Penelitian Pendidikan Kuantitatif, Kualitatif, dan R\&D. Bandung: Alfabeta.Wendari, W. N., \& Badrujaman, A. (2016). Profil permasalahan siswa sekolah menengah pertama (smp) negeri di kota bogor. Insight: Jurnal Bimbingan dan Konseling, 5(1), 134-139.

Yusuf, dan Sugandhi. (2014). Perkembangan Peserta Didik. Jakarta: PT Rajagrafindo Persada. 